\title{
Money Management by Practitioners: A Saudi Arabian View
}

\author{
Ibrahim Alramady ${ }^{1}$, Augustine C. Arize ${ }^{2}$, Krishna M. Kasibhatla ${ }^{3}$, John Malindretos ${ }^{1} \&$ Moschos Scoullis $^{4}$ \\ ${ }^{1}$ Cotsakos College of Business, William Paterson University, New Jersey, USA \\ ${ }^{2}$ College of Business and Technology, Texas A\&M, USA \\ ${ }^{3}$ School of Business and Economics, North Carolina A\&T State University, USA \\ ${ }^{4}$ School of Social Sciences, Kean University, New Jersey, USA \\ Correspondence: John Malindretos, Cotsakos College of Business, William Paterson University, New Jersey, \\ USA. E-mail: jnmalindre@optonline.net
}

Received: April 11, 2016

Accepted: June 18, 2016

Online Published: August 25, 2016

doi:10.5539/ijef.v8n9p181

URL: http://dx.doi.org/10.5539/ijef.v8n9p181

\begin{abstract}
This paper examines the practitioners of money management in Saudi Arabia about their fundamental and technical analysis and its indicators and how it contributes to improving their investment decisions. Additionally, this paper testes the effects of industry forces, such as demographics and psychographics, on stocks choosing process. Moreover, money managers are asked about the method they use to deal with the discount rate, cost of equity, to discount cash flows to present values through CAPM/APT models. Also, this papers examines the practitioners of money management in Saudi Arabia about an indicator called purity, which is an indicator used in countries that proponents and support Shariah-compliant commerce, such as Saudi Arabia.
\end{abstract}

Keywords: Saudi Arabia, portfolio management techniques, fundamental analysis, technical analysis, economic indicators, purity, sharia-compliant commerce, Tadawul, capital market authority of Saudi Arabia

\section{Introduction}

It is well known that the Saudi Arabian market is a very attractive market due to its well- regulations and the sustainable growth in comparison with other markets in the region (Al-Sadiq) (IMF Staff Report: Saudi Arabia, 2014). The concept of trading stocks and financial products are widely practiced in recent years among both individuals and firms. This paper investigates the practical techniques and aspects associated to portfolio management in Saudi Arabian financial firms. First, this paper examines whether the market is efficient or not by comparing between the three common approaches of stock picking techniques: fundamental analysis, technical analysis, and the efficiency market hypothesis approach.

Then, this paper examines other basic approaches money managers tend to relay on when they manage their portfolios. These approaches are the industry analysis, Demographics and psychographics forecasts, market timing and stock picking techniques. Each follows under a particular major approach as listed aforementioned. Saudi Arabia is a country that proponents and support Shariah-compliant banking and financing. The people of the kingdom are affected by the government view; therefore, investment funds managers tend to invest in products that comply with the Sharia as a Shariah-compliant investment solutions. This preferred method of investing in the country leads to a new concept called purity, or purification. This concept is used to refer to how closely a particular company or firm is following and practicing its financial transactions based on Sharia-law.

Also, it tests money managers' understanding of the use of the overall portfolio management techniques, which is widely followed by money managers in the U.S. market. Additionally, this paper examines the effects of money managers' educational backgrounds and certificates on their investment decisions. The practicality of portfolio managing strategies requires the implementation of various theories and methods that have been practiced in many countries in different countries in the world. Therefore, the main goal of this paper is to examine the theories and indicators that money managers in Saudi Arabia rely on in the pursuit of successful portfolio management.

\section{Research Questions \& Methodology}

As explained aforementioned, this paper is made to test and examine the indicators that the practitioners of money management use when they manage their securities in the Saudi market. I focused on examining portfolio 
managers who are in the investment departments of commercials banks, such as Samba Capital. I also tested portfolio managers who work in family-based firms, such as Nefaie Investment Group. Also, I examined portfolio managers in investment banks in the kingdom such as Jadwa investments and Aldukheil Financial Group that heavily invest in Tadawul. Also, I tried to include other multinational investment firms such as JP Morgan Saudi Arabia and Morgan Stanley Saud Arabia.

A survey of 10 questions includes numerous theories and concepts that interests the practitioners of money management in the field of finance; in addition, this survey is designed to be specifically used in the Saudi market. For instance, one of the major questions is asking money managers about the concept called purity which is a concept referred to companies that have Shariah-compliant products and services. Moreover, other questions where given to money managers to evaluate which investment approaches they rely on. In other words, money managers usually depend heavily on one of the investment approaches that includes different methods of analyzing securities, such as fundamental analysis, technical analysis, or efficiency market hypothesis. Some of the analysis used under the theories aforementioned are philosophies developed by Michael Porters who has a various books about modern strategic management and industry analysis.

Furthermore, the survey include a question about the method that the practitioners in the money management field use in order to derive the discount rate, cost of equity, that will be use to bring future cash flows to their present values. Also, one of the questions was about the educational background and professional certificates that those money managers hold to evaluate the background effect of their investment decisions. Each theory and concept used in the survey will be explained briefly in the next part to give an overview of the background that money managers depend on during their portfolio management process.

\section{Investment Approaches}

\subsection{Efficient-Market Hypothesis}

Basically, the EMH, efficient-market hypothesis, theory indicates that in general the market is efficient unless there is an external factor that effect its efficiency mechanism. The HME is divided into three different categories (Bodie et al., 2004). The weak-form of EMH, semi-strong form EMH, and strong-form EMH. First, the weak-form EMH which assumes that the value of securities is completely reflected by the market information. Second, the semi-strong form EMH assumes that securities' prices in the market are completely reflected by the availability of public information. Thirdly, the strong-form EMH assumes that securities' prices are reflected by the availability of associated information in both sectors, the public and privet sectors (Bodie et al., 2004). One of the CMA's functions is to ensure that the market has clear and effective regulations to prevent any unlawful acts, such as insider information which could affect the use of EMH theory in the Saudi market. Following this type of investment philosophy is considered as a passive management strategy. Portfolio managers tend to buy securities and hold them hoping that securities will gain more value (Bodie et al., 2004). In other words, following the logic of buy low and sell high. Also, this passive management strategy lead to an index investing which allows money managers to invest based on matching the market, and it is usually used for long-term investment decisions (Bodie et al., 2004).

\section{Fundamental Analysis}

Money manager could also use fundamental analysis to manage their portfolios. This analysis is used to determine and decide whether portfolio managers should buy a particular stock or not after they find the intrinsic value of this particular. Fundamental analysis allow portfolio managers to make their investment decision after evaluating and examining the economy, industry, and firm (Bodie et al., 2004). And, after analyzing the received data, portfolio managers categorize if the security is overprices or underprices. Therefore, based on this categorization, portfolio managers make their investment decisions (Bodie et al., 2004).

\subsection{Sector Rotations}

Sector rotation is one of the strategies money managers follow when they use fundamental analysis in their examination. This strategy allow money managers to act based on the market next move (Bodie et al., 2004).Therefore, money managers tend to position their portfolio based on their expectation of the next economic cycle move. Money managers who use follow this active strategy may purchase stocks or focus on industries that have particular characteristics, such as low P/E ratio (Bodie et al., 2004).

\subsection{Stock Picking}

Stock picking is another strategy that money managers use if they follow the fundamental analysis. This strategy helps money managers to select stocks after predicting a particular stock's next move. To predict any stock's move, detailed analysis is needed to evaluate firms' conditions. There are a variety of techniques to choose from. 
Some of these techniques are commonly used and some are not. One of the common techniques is the dividend discount model, DDM, which assumes the value of the stock based on the present value of all future dividends (Bodie et al., 2004).

$$
V_{0}=\frac{D_{1}}{(1+r)}+\frac{D_{2}}{(1+r)^{2}}+\frac{D_{3}}{(1+r)^{3}}+\cdots
$$

Where:

$V_{0}=$ value of stock today;

$D=$ future dividends;

$R=$ required rate of return.

Another common technique is the discounted cash flow which is a similar technique to the DDM method (Bodie et al., 2004). Book value per share a ratio that is commonly used which give brings good indicators through a balance sheet valuation method. Basically, the book value per share is the net worth of a company divided by the number of shares. Then, money managers could determine if the share is mispriced or not after comparing the book value per share with the market value (Bodie et al., 2004). Cash flow can be either defend as operating cash flow or free cash flow. It is believed that free cash flow is a better measurement of cash flow when comparing with cash flow from dividends (Malindretos et al., 2014). Investors tend to invest in securities that guarantee returns in dividends form; therefore, investors express value based on its present value. So, the DCF approach is commonly used due to its recognition of time value of money (Malindretos et al., 2014).

Additionally, price to sales ratio is another common indicator that money managers use; specially, when they are investing in new firms that have no earnings. And, firms that have no earnings, their price-earnings ratio is pointless; therefore, the use of price to sales ratio is frequently used when analyzing these firms. The price to sales ratio is price of a stock to the annual sales of the firm (Bodie et al., 2004). Price to operating profit is another indicator that money managers follow when they manage their portfolios.

One of the most used indicators is the price to earnings ratio, $\mathrm{P} / \mathrm{E}$, which is the price of the share to earnings per share. It is common for stock analysts to focus on this ratio due to the importance of indicator that it brings to money managers. Basically, it is a ratio of a current stock to last year's earnings per share. Which tells money managers how much investors have to pay per dollar of earnings that the firm generates.

Dividend yield ratio is a ratio that divides the dividends by the price of stocks (Malindretos et al., 2014). Companies that has low ratios usually give an indicator that this company does not produce a lot of earning and the stock is fairly overpriced. In the other hand, high ratio gives an indicator that this particular company has the ability to produce high earnings and dividends in the future (Malindretos et al., 2014).

There are other stock picking techniques that are introduced in the survey that money managers can choose from. And, these techniques are liquidation value per share, replacement value per share, degree leverage of the firm, book value over market value of equity, and Topin's Q measure (Malindretos et al., 2014).

\subsection{Market Timing}

Market timing is a technique used by the practitioners of money management that allow them to predict future price movements after entering a particular market where they could attempt alterations on projects without consideration for particular investment or industry (Arize et al., 2014). This technique can be very profi, and at the same time, it is considered a very risky technique (Arize et al., 2014).

Money managers who follow this technique tend to heavily analyze the economy to have a broader image on how the market will react to certain changes. Several components were given in the survey to gain respondents' prospective on what kind of economic factors do they analyze if they follow the market timing technique. First, inflation is a very important factor due to its effects on the economy as a whole. Predicting inflation is a very useful because if inflation increases (decreases), GDP will also increases (decrease) since they are relatively related (Arize et al., 2014). Moreover, inflation gives a determination of discount rates. Therefore, if inflation increases (decrease), the cost of equity increases (decrease) as well (Arize et al., 2014).

Productivity is a concept used to describe how high the efficiency of production is. It is an important components used in the survey given to analyze equity value. If productivity raises (falls) it leads to economic growth (decline) (Arize et al., 2014). As a result, companies tend to delay hiring, therefore, production per employee increases (decrease). Additionally, if productivity increases (decrease), companies may raise their prices to prevent reductions in their profits (Arize et al., 2014). 
There are international factors that could affect the economy. In the survey, the international factors were given in three different choices: exchange rates, trade issues, and foreign growth rates. This allow money managers to analyze the foreign effects on GDP. If forging income increases (decreases), it will allow GDP to increase (decrease) (Arize et al., 2014). Exchange rates play a major role where portfolios could be tremendously affected from international exchange rates movements against the USD (Saudi Riyal). The third component is the trade issues, and trade policies make a significant difference to both domestic producers and foreign producers (Arize et al., 2014). These trade policies usually increase exports (decrease) imports and then the GDP will react based on the difference between the imports and exports (Arize et al., 2014).

Other components are introduced in the survey as well such as the economic activity. Money managers in the kingdom can choose different indicators when analyzing their investment decisions. Then can choose from the three economic indicators, leading, lagging, and coincidental (Arize et al., 2014). In other words, based on their expectation of the economy they choose from the three indicator: leading, lagging, and coincidental and act based upon them.

\section{Technical Analysis}

Technical analysis is still fairly used in the Kingdom, basically it is an estimation of future price of securities based on past information about securities' prices and volumes movements (Bodie et al., 2004). There are various techniques and strategies used under the technical analysis school. The survey that was given to money managers in Saudi Arabia included support and resistance levels. The support level is the price range of a security where analysts would expect a significant demand for this particular security. In the other hand, a resistance level is the price range of a security where analysts expect a significant supply of security (Bodie et al., 2004).

Moving average is another commonly used component among money managers. Basically, moving average of previous prices could give an indicator of the future price movement for the long run (Bodie et al., 2004). It is commonly used to choose a 200-day moving average and it is considered as a popular measure for aggregate markets, (Bodie et al., 2004).

Another component of technical analysis is relative strength. It is believed that if a trend has taken a place, this trend will not be affected until another even occurred and influence this trend. In other words, if a stock has a great performing, it will continue to do so until another event happen to this stock which effects the stock performance (Bodie et al., 2004). Momentum is a component that is also introduced in the survey given to money managers in the Kingdom. It refers to the difference between a stock current closing price and the close price of the same stock a period of time in the past, days ago.

\subsection{Industry Analysis}

The industry analysis is very important because usually there is a positive correlation between companies in the same industry. Analyzing industry allow money managers to position their funds based on the conclusion they get after analyzing different industries. There are various methodologies to analyze an industry. First, understanding the business cycle. After analyzing and monitoring economic components of an industry, money manager will have the ability to either beat the market or forecasts or evaluate different market alternatives (Bodie et al., 2004). The business life cycle have a five-stage model. First, pioneering development. Second, rapid accelerating growth, Third, mature growth. Fourth, stabilization and market maturity. Fifth, deceleration of growth and decline (Bodie et al., 2004).

Nowadays, technology have a tremendous effect in any industry in terms of how products and services are produced and delivered (Bodie et al., 2004). For instance, the majority of retailors use barcode scan to track their products and orders. This technology gives companies the ability to track orders and have the capability to know exactly what the consumers need. (Bodie et al., 2004). Therefore, technology allow companies to operate with high-efficient mechanism, which leads to high return and profits.

Money managers also follow other various approaches of analyzing industries. One of the most followed approves is the Michael Porter's five forces that governs competitions in any industry (Porter, 1979). Money manager tend use this approach prior to the investment strategy development. Porter's study stated that there are five business forces that evaluates if a particular industry is attractive or not. The five forces are threat of new entrants, bargaining power of suppliers, bargaining power of customers, threat of substitute product or service, and rivalry of competitors (Porter, 1979).

\subsection{Demographics and Psychographics Analysis}

Additionally, some money managers take the research forward to analyze the demographics and psychographics 
of an industry or even a whole nation. Analyzing the age disruption of a group people is known to be one of the demographics components that some managers follow. For example, in the U.S. there is a group of people known as the baby-boomers generation (Bodie et al., 2004). This generation was born between the end of the World War II and the 1960s. There was a baby boom in this particular generation. This Generation have has their own of purchasing power where it definitely effect the performance of some industries than others (Bodie et al., 2004).

There are also other components that could influence some industries. These components are geographical distributions, age distributions, and income distributions. Other components can be analyzed as well before investing in an industry and they are population growth, family formations, ethnic distributions, head of family, education of family, and occupation of family.

\section{Methodologies to Derive the Discount Rate (COE)}

There are several methods to derive the discount rate, the cost of equity, and determining this discount rate allow companies to use this rate to discount their future cash flows to present value. One of the most commonly used method is the capital asset pricing model, CAPM, which is a model that was developed by William Sharpe and John Lintner in the mid-1960s and resulting in a Nobel Prize for William Sharpe in 1990 (Fama \& French, 2004). CAPM is a basically a model that tells investors what should be the required or expected rate of return on risky assets. By providing an appropriate discount rate, money managers tend to use this rate to estimate the cost of capital for firms and also to evaluate the performance of their portfolios (Fama \& French, 2004). There are assumptions that have to be made in this model such as, investors are risk averse, which means lower risk is more preferable to investors. Also, the model assumes that investors only care about two variables, mean and variance, in their one-period investment returns. In addition, it assumes that investors could lend and borrow any amount of money at a risk-free rate. Also, the security market line, SML, is used to have a relation between the expected return and the beta (Bodie et al., 2004). The CAPM model is shown below.

$$
E\left(R_{j}\right)=R_{f}+\beta_{j}\left[E\left(R_{m}\right)-R_{f}\right]
$$

Where:

$E\left(R_{j}\right)=$ expected return on asset $j$;

$R_{f}=$ risk-free rate;

$E\left(R_{m}\right)=$ expected return on market portfolio;

$\beta_{j}=$ Beta, $\operatorname{COV}\left(R_{j}, R_{m}\right) /\left(R_{m}\right)$.

Another way to derive the discount rate is the arbitrage pricing theory, APT, which is a theory that is known to be an alternative to CAPM and it was introduced by Stephen Ross during the 1970s (Ross, 1976). APT is also known to be less restrictive than CAPM because it does not require the expected return on market. Also, APT can be contrasted with the single-factor CAPM. APT predicts the value of an expected mispriced asset based on the relationship between same assets and several common risk factors (Bodie et al., 2004). In other words, it uses the expected return of risky assets and the risk premium along with other macro-economic components (Lee \& Cummins, 1998). The APT formula is shown below.

$$
K_{e i}=\lambda_{0}+\lambda_{1} b_{i 1}+\ldots+\lambda_{k} b_{i k}
$$

Where:

$K_{e i}=$ cost of equity estimation;

$\lambda_{0}=$ common return on all zero-beta assets;

$\lambda_{k}=$ premium for risk associated with factor $k$;

$b_{i k}=$ factor loading of asset $i$ to factor $k$.

Additionally, there is another method to estimate the cost of equity and it is known as the dividend yield plus growth model. To be able to use this model, money manager must estimate the required rate of return, and the expected constant growth rate of dividends (Bodie et al., 2004). Therefore, the formula used to estimate the cost of equity is shown below.

Where:

$$
k=D / V+g
$$

$k=$ the required rate of return;

$D=$ the dividend payment; 
$V=$ value of security;

$g=$ the constant growth rate of dividends.

\subsection{Portfolio Evaluation Methods}

There are different methods to measures and evaluate the performance of investment portfolio. Two famous measures are Sharpe ratio, also known as reward-to-volatility ratio, and Treynor ratio (Bodie et al., 2004). First, Sharpe ratio depends on the CAPM, which was explained earlier in this paper, particularly with capital Market Line, CML. It is a measures the total risk associated with the investment portfolio by including the standard deviation with the systematic risk, or the Beta. The formula that should be applied to receive Sharpe measure is shown below (Bodie et al., 2004).

$$
S=\frac{\overline{R_{i}}-\overline{R F R}}{\delta_{i}}
$$

Where:

$\overline{R_{i}}=$ the average rate of rate of return for the investment portfolio

$\overline{R F R}=$ the average rate of return on risk-free assets

$\delta_{i}=$ the estimated standard deviation of the rate of return on the investment portfolio

On the other hand, Tynore ratio is another performance measure that is commonly used in the field of portfolio investment. This measure focuses on two assumptions made on risks. First, the general fluctuations produce risks in the market (Bodie et al., 2004). Second, risk is expected as a result of special fluctuations in portfolios' securities. Treynor method of evaluation includes the risk premium in the numerator, $\overline{R_{i}}-\overline{R F R}$. And, the risk premium return per unit of risk in the portfolio is in the denominator, which is the Beta (Bodie et al., 2004).

\subsection{Purity}

The Muslim population represents about 20 percent of the world's population and growing at about 1.8 percent annually. It is estimated that Muslims in the world have between $\$ 250$ billion and $\$ 1$ trillion for investment purposes (Chow, 2006). One of the most growing segments of the global finance industry is the Islamic finance, or Sharia-compliant finance Islamic finance is basically the practice of finance operations that comply with the requirement of the Islamic law, Sharia law (Gait \& Worthington, 2007). And, the Sharia law is derived from the Holy Quran and the tradition of Prophet Muhammad, which is known as Sunna (Gait \& Worthington, 2007). Additionally, the fundamental source of law in Saudi Arabia is Sharia-law. There are numerous general principles of Sharia-compliant finance that companies take into considerations when operating and performing under the Sharia-law.

The Sharia-law prohibits some business practices that may harm the society. First, Riba is strongly prohibited in Islam, which is known as usury and fixed-interests no matter if this interest is smaller or larger than the principle. Second, Sharia-compliant commerce forbids Gharar, which means risk and uncertainty; therefore, it is required a full disclosure of information without any asymmetrical information in any business practices (Gait \& Worthington, 2007). Thirdly, it also prohibits any kind of participation in dealing with sinful and socially-irresponsible activities, such as gambling and other pure game of chance, which is known in Arabic as Maysir (Gait \& Worthington, 2007). The religious polices also prohibit the production of alcohol beverages, tobacco, and production of pornography (Gait \& Worthington, 2007).

Other general principles of Sharia-law is the requirement of collecting and paying the Zakah. And, Zakah is a financial support from people to those who suffer from poverty (Gait \& Worthington, 2007). The Zakah rate is 2.5 percent due annually on gold, silver, money, land, and other owned fixed asset. Takaful is the Islamic method of delivering insurance services which takes into consideration all the Sharia-law of managing financial products (Gait \& Worthington, 2007). There is a contradiction between insurance and the concept of Gharar, due to the uncertainty that could be brought by the policy holder to the insurance provider. Islamic law encourages cooperative insurance; therefore, the premium and the coverage amount from both parties have to be predetermined and pre-specified (Gait \& Worthington, 2007).

There are various methods of finance under the Sharia-law practiced by Islamic banks and institutions. First, Mudarabah, which is known to be as a partial equity partnership (Gait \& Worthington, 2007). Also, it is a contract between two parties or more, lender(s) and borrower(s), where the borrower promise the lender to return the invested money at a predetermined date and predetermined ratio of profit earned. Second, Musharakah which is basically, a full-equity partnership between two parties or more (Gait \& Worthington, 2007). Thirdly, 
Murabaha is another type Sharia-compliant financing and basically it is an agreement, usually between financial institutions and clients that allow banks buying a particular purchase and reselling to clients at a predetermined price, and purchase (Gait \& Worthington, 2007). Also, the method of repaying the purchase should be pre-specified and agreed on by both parties. Fourthly, Bai Muajjall is another form of financing; and it means receiving the purchase now but paying the predetermined value at a predetermined date (Gait \& Worthington, 2007).

The fifth type of Sharia-compliant financing is Bai Salam is the opposite of Bai Muajjall, and basically, is a contract where the value of the purchase is received today and delivery of the purchase is predetermined (Gait \& Worthington, 2007). Sixthly, Istisna is considered one of the most recent methods of Sharia-compliant financing and it means paying for the good while it is manufacturing. The last type of the Sharia-compliant financing is Ijarah, or leasing. And, Ijarah is a contract between lessor and lessee where lessee use the capital asset of the lessor in exchange with a predetermined compensation (Gait \& Worthington, 2007). All these types of financing aforementioned comply with the Sharia-law. And, companies that completely follow the Sharia-compliant methods of trading in the business world must take into consideration all polices and principles of Sharia-law.

A new concept recently to be commonly used known as purity or purification, known in Arabic as Naqawah. Basically, it is referred to how strictly and closely listed companies and firms are following the principles of Sharia-law of finance. In other words, it is an indicator used by money managers in countries that proponents and support Shariah-compliant financing, such as Saudi Arabia. There are purity percentage levels of all companies listed in the Saudi Exchange Market, Tadawul, and money managers who only invest in Shariah-compliant shares of Saudi companies will use this purity indicator to make their Shariah-compliant investment decisions.

A Shariah-board in companies are usually asked to evaluate the company's operations to ensure the proper implementation of Shariah-compliant methods of finance. This board is usually come with a strong Islamic background in the field of Islamic commerce and regulations. This Shariah-board disclose their decisions through publications, which is used as guidelines in companies' operations. In addition, this Shariah-board of scholars evaluates companies' daily transactions and it gives a percentage level of how closely they are in terms of following the Shariah-law. Therefore, some clients may only wish to invest their funds in portfolios that are designed to invest only Shariah-compliant shares of Saudi companies. So, they use this purity percentage level of firms to make their Shariah-compliant investment decisions. Each bank and firm hire their own Shariah-board. And, this could create different religious decisions; therefore, the government has to play a major role with this issue by establishing a governmental department that is responsible for evaluating the purity percentages of companies in Saudi Arabia.

Every year Shariah -scholars disclose a complete list of companies and their purity percentages level. Therefore, people who wants their investment to be 100 percent pure will need to discard the extra profit based on the non-pure rate. (In Appendix D, an example in Arabic of a list of companies that identified by their non-purity percentage levels, so people will need to eliminate this non-pure from the overall generated profit).

\section{Research Design \& Delivery and Responses}

To examine money managers in Saudi Arabia, I designed a money management survey that includes all the indicators and theories that were explained through this paper, a sample of the survey is shown in Appendix C. According to the Saudi Stock Exchange Market, Tadawul, there are 38 investment banks operating in the Saudi Arabian market today. I contacted money managers of these companies via emails as well as other fund managers in wealth management companies in the Kingdom.

To ensure a high rate of responses, I sent the survey invitation four times to more than 130 money management professional in Saudi banks and financial firms through a user-friendly website known as, questionpro.com, which facilitates the delivery of the survey and the organization of the data. In the email invitation, I clarified the purpose of the survey, which is to gain money managers' perspectves on what financial and economic indicators and theories do they use in their pursuit of portfolio management. In addition, I noted in the invitation that their responses will be kept completely confidential. And, there was no need to share their names, the company they work for, or the size of their portfolios.

In the survey, I asked money managers in the Kingdom to answer ten questions by indicating their emphasis. And, the range of importance is from zero percent for a choice they do not emphasize at all to one hundred percent for a choice they weigh extremely heavily in their pursuit of portfolio management. 


\section{Results}

The data was received from a sample of 20 respondents from money management professionals where they anonymously disclosed their methods of managing their investment portfolios (See a complete set of the received data is shown in Appendix D). First, among the 20 respondents, the practitioners of money management in Saudi Arabia tend to heavily relay on fundamental analysis with 62.65 percent. Only, 20 percent of them uses the technical analysis, and only 17.65 percent believe in the efficient-market hypothesis. Therefore, these percentages show that money managers tend to believe in their analysis and skills and they believe they can do better than average after following the diverse methods of investment analysis.

Second, respondents who chose fundamental analysis rely on stock picking technique with 80 percent. And, market timing technique comes in the second place with 49 percent, while only money manager depend their analysis by 31 percent through the sector rotation technique. Thirdly, one main question in the survey was about the market timing analysis tools that money managers use to forecast and predict the market movements. Money managers in the Kingdom tend to relay on a collection of tools to have a better image of the condition of the Saudi market. The most used tool is the financial conditions analysis with 43 percent of dependency. Then, productivity as an indicator comes in the second place with 40 percent, then leading indicator with 30 percent. Additionally, then what money managers value are fiscal policy, inflation, and forecasts of GDP with 27 percent, 24 percent, and 19 percent of dependency rates, respectively (see Figure 1 and Appendix D for detailed information).

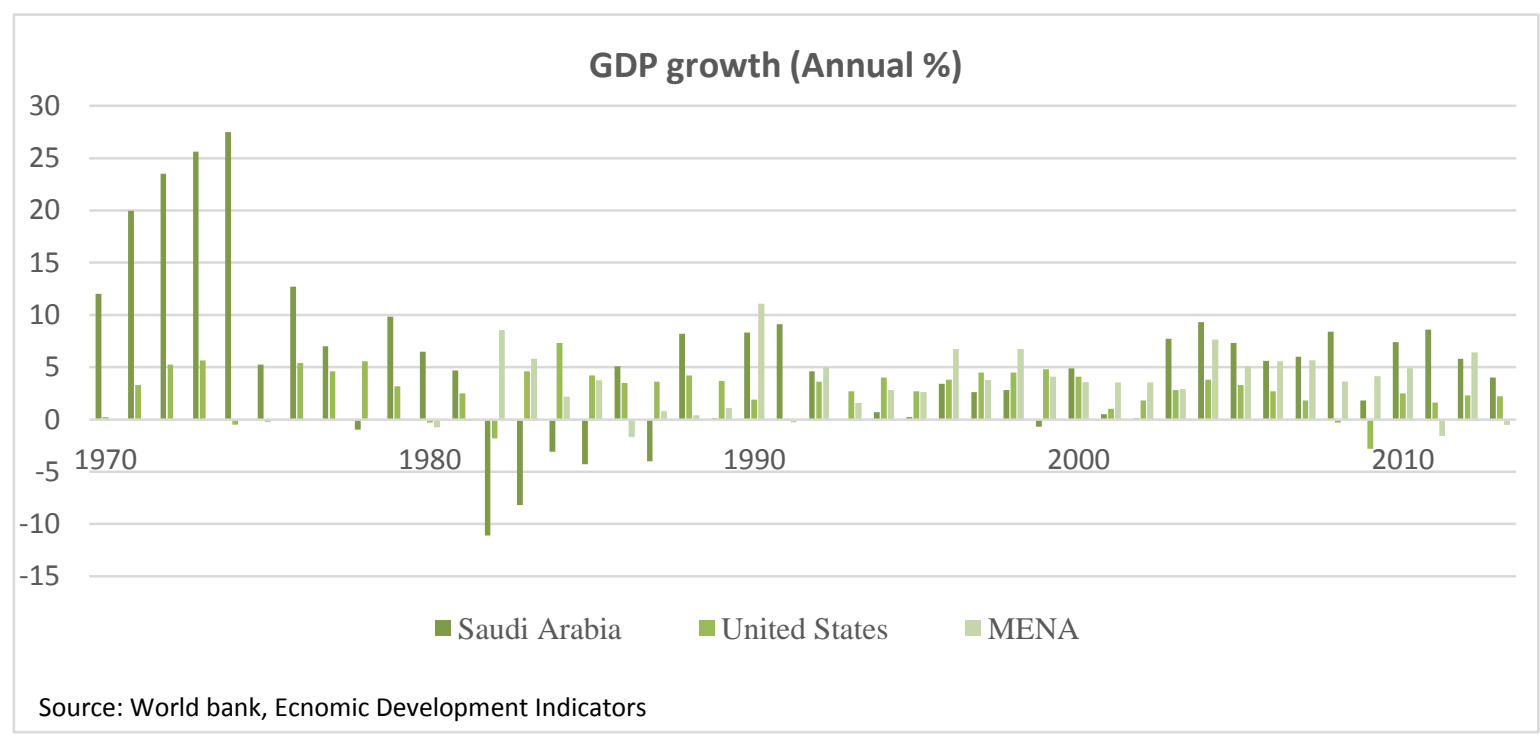

Figure 1. GDP growth (annual percentage)

Other questions were about the industry analysis that money managers tend to follow prior making their investment decisions. The participants were asked about their determents of industry profitability. The most popular choice of industry analysis is analyzing the profit margins with respondents depend their total analysis on this tool with 23.7 percent. The second tool is the analyzing the life cycle with 14.5 percent and the third most used tool is the cost structure with 10.2 percent. The second question about analyzing an industry was asking money managers about their use of demographics and/or psychographics to forecast profitability potential. The most used tool is income distribution with having respondents depending on this analysis by 22.2 percent. The second and third most used type of analysis are the age distribution and population growth with 18.9 percent and 15.6 percent, respectively (see Appendix D for detailed information).

Moreover, stock picking technique is another method of analyzing the value of a stock. Money managers in the Kingdom seems to rely heavily on DCF where it comes the most used technique among other stock picking technique with 45 percent. Then, the discounted dividends comes as a second most used tool with 30 percent depending on it. The third most used too is price earning per share with 20 percent depending on it respectively and then dividend yield comes after that with 17 percent (see Appendix D for detailed information). 
Also, money managers were asked about their tools of technical analysis. And, the respondents the most used technical analysis tool is the support and resistance level with 78 percent. Then respondents showed their dependency rate of following the tools of technical analysis as followed: moving average, momentum, and relative strength with 65 percent, 47 percent, and 43 percent, respectively (see Appendix D for detailed information).

In addition, there various ways to derive the discount rate, cost of equity, there is one question that showed money managers in Saudi tend to relay on CAPM with 53.2 percent of respondents depending on it. The second most used model is the arbitrage pricing theory with 25.2 depending on it. And, finally about 21.4 percent of respondents depend on the dividend yield plus growth model to derive the discount rate.

As explained earlier in this paper about the importance of Shariah-compliant investment solutions in the Muslim country, Saudi Arabia. The popularity of investing in pure products is becoming very attractive. Therefore, money managers were asked if they take into considerations the type of the company they want investing in, weather if it complies with the Shariah or not. 35.2 percent of respondents believe that companies they want to invest in have to be at least 70 percent pure. While 17.6 percent believe it have to 100 percent pure. Also, 17.6 percent believe that it purity in the company should be between 70-50 percent. And, two respondents stated that they prefer not to answer this question.

Among the 20 participants, there are $8 \mathrm{MBA}$ holders as an educational degree. While the most professional certificates is the CME-1 with 7 holders which is a certificate that is designed to test financial professionals in the kingdom about their knowledge on securities and regulations. 2 of respondents stated that they hold the CFA® certificate. Among the 20 participants, eight of them rated their performance as good and five of them rated their performance as excellent. Additionally, one respondent added a comment about holding the ICertIM, which is the international Certificate in Investment Management. And, also another respondent made a comment about the CMA certificates, which is globally recognized, advanced-level credential appropriate for accountants and financial professionals in business

Additional comments were made by participants where two of them have specified that they follow a type of analysis called Elliot waves. And, it is basically it is a type of analysis developed by Ralph Nelson Elliot in the 1920s and it predicts the market cycle which comes as a consequence of investors' reactions. In other words, Elliot waves are the analysis on the repetitive upward and downward swings as a result of investors' decisions (Elliott Wave Theory).

\section{Recommendations for Future Research}

There are many aspects that could push this current research forward. Due to the generality of this research, there are many areas and practices that could be studied in the Saudi Arabian market. First, what the methodologies is used to calculate the purity percentages and under what circumstances is one area that can be studies. Also, there could be a study on the effect of the educational backgrounds and professional certificates on investment decisions made by money managers in Saudi Arabia. Moreover, there could be a study on the risk-free rate used when calculating CAPM to get the discount rate, cost of equity, in the Saudi Market.

\section{Conclusion}

This paper examines the type of theories and indicators that money managers follow in Saudi Arabia when they manage their investment portfolios. Some of these theories are heavily-dependent on and some are not. A money management survey that included ten different questions of different areas of investment methods were given to more than 130 money management professionals in the Kingdom of Saudi Arabia starting from mid-January 2015 to mid-April 2015. The survey was sent up to four times to those who did not participate in the first, second, and third survey invitations. The total participation in the survey is 20 participants who delivered very interesting information about the theories and indicators used in the Saudi Arabian Market today.

\section{References}

Al-Sadiq, A. (n. d.). Economic convergence in Saudi Arabia. Economist, 153-159.

Arize, A. C., Kallianotis, I. N., Malindretos, J., Maruffi, B. L., \& Scoullis, M. (2014). Market timing techniques: Its use by practitioners of money Management. Accounting and Finance Research, 3(1), 106. http://dx.doi.org/10.5430/afr.v3n1p106

Arize, A., Christoffi, A., Malindretos, J., Maruffi, B., \& Scoullis, M. (2013). An Examination of the Efficient Market Hypothesis: The Evidence from Practitioners of Money Management. Journal of Management Research, 5(3), 108-114. http://dx.doi.org/10.5296/jmr.v5i3.3022 
Arize, A., Kallianotis, I., Liu, S., Malindretos, J., \& Maruffi, B. (2014). The Preponderance of stock picking techniques: The practice of applied money managers. Accounting and Finance Research, 3(2). http://dx.doi.org/10.5430/afr.v3n2p87

Arize, A., Maruffi, B., Kasibhatla, K., Malindretos, J., \& Scoullis, M. (2013). The Determinants of Industry Analysis: An Application to Practitioners of Money Management. Journal of Management Research, 5(1), 207-2013.

BIS, The Bank for International Settlements. (2012). Payment, clearing and settlement systems in Saudi Arabia. Basel, Switzerland.

Bodie, Z., Kane, A., \& Marcus, A. J. (2004). Essentials of Investments. New York, USA: McGraw Hill.

Brown, G. (1999). Volatility, Sentiment, and Noise Traders. Financial Analysts Journal, 55(2), 82-90. http://dx.doi.org/10.2469/faj.v55.n2.2263

Capital Market Authority. (2015, February). CMA Departments. Retrieved from http://www.cma.org.sa/En/AboutCMA/CMA_Department/Pages/default.aspx

Chow, C. (2006). City and Country: Recycling Petro Dollars. The Edge, September 18.

Clark, R. G., \& Statman, M. (1998). Bullish or Bearish? Financial Analysts Journal, 54(3), 63-72. http://dx.doi.org/10.2469/faj.v54.n3.2182

Cordell, D. M., Langdon, T. P., \& Lemoine, C. W. (2006). Bridging the Gap: Academic Research that is Relevant to Practitioners. Journal of Financial Service Professionals, 60(6), 72-78.

Cordell, D. M., Langdon, T. P., \& Lemoine, C. W. (2008). Academic Research that is Relevant to Financial Service Professionals. Journal of Financial Service Professionals, 62(6), 36-44.

Cordell, D. M., Langdon, T. P., \& Lemoine, C. W. (2012). Academic Research that Practitioners Can Use. Journal of Financial Service Professionals, 66(2), 88-96.

Cordell, D. M., Langdon, T. P., \& Tacchino, K. (2010). Financial Planning Research: Articles that Practitioners Can Use. Journal of Financial Service Professionals, 64(6), 75-84.

Country forecast Saudi Arabia may 2014. (2014). New York: The Economist Intelligence Unit N.A., Incorporated. Retrieved from http://ezproxy.wpunj.edu:2048/login?url=http://search.proquest.com/docview/1521775852?accountid=151

Fama, E. F., \& French, K. R. (2004). The capital asset pricing model: Theory and evidence. Journal of Economic Perspectives, 18, 25-46. http://dx.doi.org/10.1257/0895330042162430

Gait, A., \& Worthington, A. C. (2007). A primer on Islamic finance: Definitions, sources, principles and methods. Faculty of Commerce-Papers, 341.

International Monetary Fund. (2014). IMF Staff Reports: Saudi Arabia - 2014 Article IV Consultation - Staff Report; Press Release; Public Information Notice on the Executive Board discussion of the staff report that concluded the Article IV consultation with Saudi Arabia. USA International Monetary Fund. Retrieved from http://www.imf.org/external/pubs/ft/scr/2014/cr14292.pdf

Investopedia Staff. (n. $\quad$ d.). Elliott Wave Theory. Retrieved from http://www.investopedia.com/articles/technical/111401.asp

Khan, M. (2012). Kingdom of Saudi Arabia's Macro-economy 2011-2012. Defence Journal, 16(4), 76-79.

Lee, A., \& Cummins, J. (1998). Alternative models for estimating the cost of equity capital for property/casualty insurers. Review of Quantitative Finance and Accounting, 10(3), 235-267. http://dx.doi.org/10.1023/A:1008291917092

Muhammad, R. K. (2013). Mapping entrepreneurship ecosystem of Saudi Arabia. World Journal of Entrepreneurship, Management and Sustainable Development, 9(1), 28-54. http://dx.doi.org/10.1108/20425961311315700

Porter, M. E. (1979). How competitive forces shape strategy. Harvard Business Review, 57(2).

Ross, S. A. (1976). The arbitrage theory of capital asset pricing. Journal of Economic Theory, 13(3), 341-360. http://dx.doi.org/10.1016/0022-0531(76)90046-6

Saudi Stock Exchange (Tadawul). (2008). Annual Statistical Report. Riyadh, Saudi Arabia.

The Report. (2007). Emerging Saudi Arabia 2007. London, UK: Oxford Business Group. 
The World Bank. (2009). Report on the Observance of Standards and Codes (ROSC): Corporate Governance. Retrieved from http://www.worldbank.org/ifa/rosc_cg_saudia_arabia.pdf

The World Bank. (2015). Global Economic Prospects: Understanding the Plunge in Oil Prices: Sources and Implications

Retrieved

from http://www.worldbank.org/content/dam/Worldbank/GEP/GEP2015a/pdfs/GEP2015a_chapter4_report_oil.p df.

\section{Appendix A}

\section{List of Abbreviations}

MENA

IMF

WTO

GCC

SAMA

SAGIA

IPO

CMA

TADAWL

TASI

CSD

EHM

DDM

CML
Middle East and North Africa Region

International Monetary Funds

World Trade organization

Gulf Cooperation Council

Saudi Arabian Monetary Agency

Saudi Arabian General Investment Authority

Initial Public Offerings

Capital Market Authority

Saudi Stock Exchange

Tadawul All-Share Index

Central Securities Depository

Efficiency Market Hypothesis

Dividend Discount Model

Capital Market Line

\section{Appendix B}

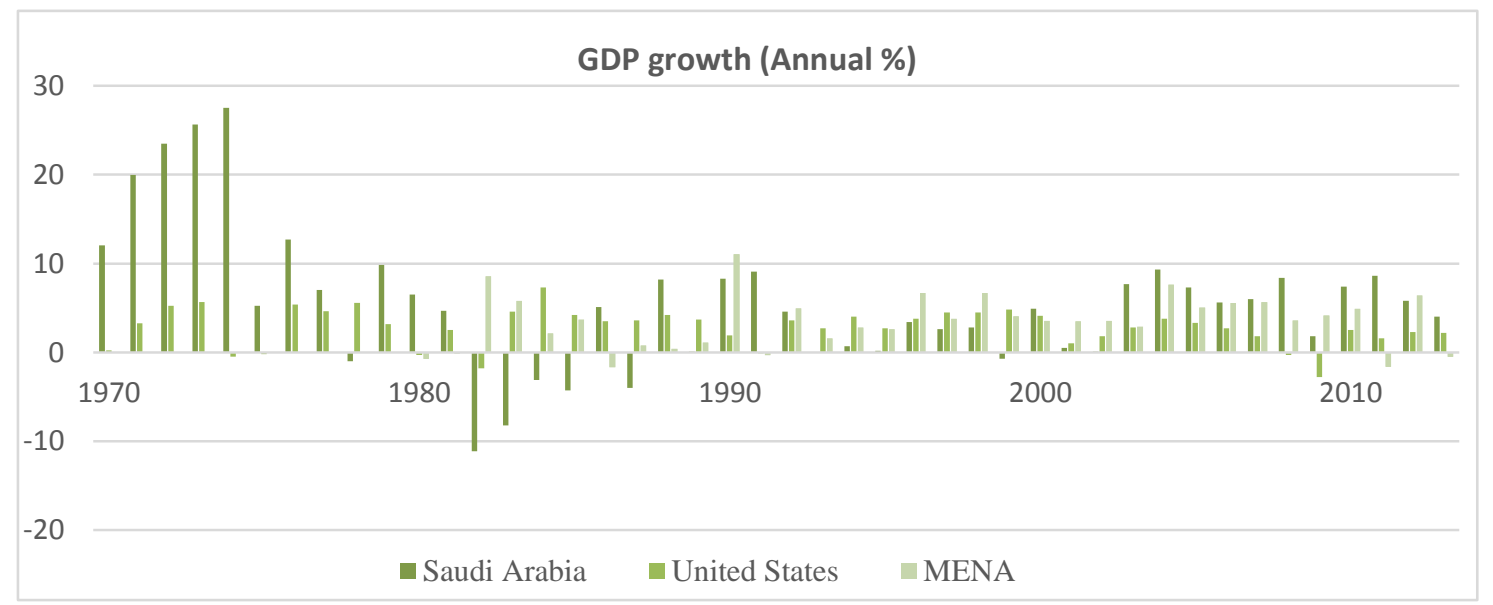

Figure 1. GDP growth (annual percentage)

Source: World bank, Ecnomic Development Indicators.

\section{Appendix C}

\section{Survey of Money Management in Saudi Arabia}

Please, answer by indicating your emphasis. The range of importance is from zero percent for a choice you do not emphasize at all to one hundred percent for a choice you weigh extremely heavily in your pursuit of portfolio management. 
A. Which approach(s) of investments do you relay on?

1- Efficiency market hypothesis

2- Fundamental analysis

3- Technical analysis

B. If you use fundamental analysis, which technique do you use?

1- Market timing

2- Sector rotation

3- Stock picking

C. If you use market timing as a technique, on which of the following do you put more weight in forecasting the economy?

1- Indicators

a. Leading

b. Lagging

c. Coincidental

2-Inflation

3-Productivity

4-Fiscal policy

5-Financial Conditions

6-Consumer expectations

7-Surveys of business sentiment

8-Forecasts of GDP

9- International Factors

a) Exchange rates

b) Trade issues

c) Foreign growth rates

D. If you use industry analysis, what aspects of the industry do you emphasize?

1- Life cycle

2- Profit margins

3- Cost structure

4- Legality and regulation

5- Demographics

6- Psychographics

7- Technology

8- Rivalry of competitors

9- Threat of new entrants

10- Threat of substitute products

11- Bargaining power of suppliers

E. If you use demographics and/or psychographics to forecast profitability potential in a certain market, how do you weigh the following different aspects of that market?

1. Geographical distribution

2. Age distribution

3. Income distribution

4. Population growth 
5. Family size

6. Family formation

7. Ethnic distribution

8. Head of the family

9. Education of Family

10. Occupation of family

11. Attitudes of family

F. If you use stock picking, which specific technique do you use?

1. Discounted dividends

2.Discounted cash flow

3.Book value per share

4.Liquidation value per share

5.Replacment value per share

6.Price to sales

7.Price to operating profit

8.Price to earnings per share

9.Market capitalization

10.Degree of leverage of the firm

11.Book value over market value of equity

12.Dividend yield

13.Tobin's q

G. If you use technical analysis, which particular technique do you use?

1. Head and shoulders

2. Moving average

3. Momentum

4. Confidence index

5. Margin debt

6. Breadth of the market

7. Block Uptick-Downtick ratio

8. Support and resistance level

9. Relative strength

10. Bar charting

11. Point and figure chart

12. Multiple indicator charts

13. Volum

14. Bulishness on stock index futures

15. Mutual fund cash position

16. Credit balances in brokerage accounts

17. Investment advisory opinions

H. What method do you use to derive the discount rate (cost of equity) to discount the cash flows to present values?

1. Capital Asset pricing Model (CAPM)

2. Arbitrage pricing theory (APT) 


\section{Dividend yield plus growth}

I. If your portfolio is only designed to invest in Shariah-compliant shares of Saudi companies, what is the minimum purity percentage level of firms you may wish to invest in? (i.e., I only invest in firms that are... )
1. $100 \%$ Pure
2. $70 \%>$ Pure
3. $70 \%-50 \%$ Pure
4. $50 \%<$ Pure
5. I prefer not to answer

J. What kind of educational background and/or professional certificates do you have?
1. MBA
2. $\mathrm{CFA} \circledast$
3. $\mathrm{CPM}$
4. CPA
5. FRM
6. CWM
7. CME-1
8. CME-2
9. CME-3

K. How would you rate your performance, i.e., the rate of return adjusted for risk such as in a Sharpe or Treynor measures?
1. Excellent
2. Good
3. Average
4. Below Average

L. If you follow any other additional indicators/theories from the 11 questions aforementioned, please write them below by indicating the question number and the usage of your indicator or theory.

\section{THANK YOU FOR YOUR ANSWERS.}

\section{Appendix D}

\section{Survey of Money Management in Saudi Arabia}

Please, answer by indicating your emphasis. The range of importance is from zero percent for a choice you do not emphasize at all to one hundred percent for a choice you weigh extremely heavily in your pursuit of portfolio management.

\begin{tabular}{|c|c|c|}
\hline & Count & Completed / Started \\
\hline Completed & 20 & $17.39 \%$ \\
\hline Started & 115 & \\
\hline
\end{tabular}

A. Which approach(s) of investments do you relay on?

$\begin{array}{lll}\text { Answer } & \text { Count } & \text { Percent } \\ \text { 1- Efficiency market hypothesis } & 300 & 17.65 \% \\ \text { 2- Fundamental analysis } & 1060 & 62.35 \% \\ \text { 3- Technical analysis } & 340 & 20.00 \% \\ \quad \text { Total } & 1700 & 100 \%\end{array}$


B. If you use fundamental analysis, which technique do you use?

$\begin{array}{lllc}\text { Answer } & \text { Count } & \text { Percent } & \text { (Count/ fundamental analysis count) } \\ \text { 1- Market timing } & 523 & 30.76 \% & 49 \% \\ \text { 2- Sector rotation } & 333 & 19.59 \% & 31 \% \\ \text { 3- Stock picking } & 844 & 49.65 \% & 80 \% \\ \quad \text { Total } & 1700 & 100 \% & \end{array}$

C. If you use market timing as a technique, on which of the following do you put more weight in forecasting the economy?

$\begin{array}{llll}\text { Answer } & \text { Count } & \text { Percent } & \text { (Market Timing Count) } \\ \text { 1. Indicators } & & & \\ \text { 2. -----> Leading } & 182 & 12.05 \% & 35 \% \\ \text { 3. -----> Lagging } & 104 & 6.89 \% & 20 \% \\ \text { 4. ----> Coincidental } & 105 & 6.95 \% & 20 \% \\ \text { 5. - Inflation } & 124 & 8.21 \% & 24 \% \\ \text { 6. - Productivity } & 207 & 13.71 \% & 40 \% \\ \text { 7. - - Fiscal policy } & 144 & 9.54 \% & 27 \% \\ \text { 8. - Financial conditions } & 223 & 14.77 \% & 43 \% \\ \text { 9. - Consumer expectations } & 97 & 6.42 \% & 18.5 \% \\ \text { 10. -Surveys of business sentiment } & 69 & 4.57 \% & 13 \% \\ \text { 11. - Forecasts of GDP } & 110 & 7.28 \% & 19 \% \\ \text { 12. - International factors } & & & \\ \text { 13. ----> Exchange rates } & 44 & 2.91 \% & 8 \% \\ \text { 14. ----> Trade issues } & 36 & 2.38 \% & 5 \% \\ \text { 15. ----> Foreign growth rates } & 64 & 4.24 \% & 12 \% \\ \quad \quad \text { Total } & 1510 & 100 \% & \end{array}$

D. If you use industry analysis, what aspects of the industry do you emphasize?

\begin{tabular}{lll} 
Answer & Count & Percent \\
1- Life cycle & 245 & $17.50 \%$ \\
2- Profit margins & 333 & $23.79 \%$ \\
3- Cost structure & 144 & $10.29 \%$ \\
4- Legality and regulation & 89 & $6.36 \%$ \\
5- Demographics & 81 & $5.79 \%$ \\
6- Psychographics & 53 & $3.79 \%$ \\
7- Technology & 115 & $8.21 \%$ \\
8- Rivalry of competitors & 131 & $9.36 \%$ \\
9- Threat of new entrants & 55 & $3.93 \%$ \\
10- Threat of substitute products & 68 & $4.86 \%$ \\
11- Bargaining power of suppliers & 86 & $6.14 \%$ \\
\multicolumn{1}{c}{ Total } & 1400 & $100 \%$
\end{tabular}

E. If you use demographics and/or psychographics to forecast profitability potential in a certain market, how do you weigh the following different aspects of that market?
Answer
Count
Percent
1. Geographical distribution 


\begin{tabular}{lll} 
2.Age distribution & 284 & $18.93 \%$ \\
3.Income distribution & 334 & $22.27 \%$ \\
4.Population growth & 234 & $15.60 \%$ \\
5.Family formation & 76 & $5.07 \%$ \\
6.Ethnic distribution & 58 & $3.87 \%$ \\
7.Head of the family & 47 & $3.13 \%$ \\
8.Education of family & 113 & $7.53 \%$ \\
9.Occupation of family & 124 & $8.27 \%$ \\
\multicolumn{1}{c}{ Total } & 1500 & $100 \%$
\end{tabular}

F. If you use stock picking, which specific technique do you use?

$\begin{array}{llll}\text { Answer } & \text { Count } & \text { Percent } & \text { (Stock Picking Count) } \\ \text { 1. Discounted dividends } & 254 & 15 \% & 30 \% \\ \text { 2.Discounted cash flow } & 388 & 22.82 \% & 45 \% \\ \text { 3.Book value per share } & 140 & 8.24 \% & 16.5 \% \\ \text { 4.Liquidation value per share } & 41 & 2.41 \% & 5 \% \\ \text { 5.Replacement value per share } & 40 & 2.35 \% & 5 \% \\ \text { 6.Price to sales } & 122 & 7.18 \% & 14 \% \\ \text { 7.Price to operating profit } & 138 & 8.12 \% & 16 \% \\ \text { 8.Price to earnings per share } & 167 & 9.82 \% & 20 \% \\ \text { 9.Market capitalization } & 79 & 4.65 \% & 9.3 \% \\ \text { 10.Degree of leverage of the firm } & 111 & 6.53 \% & 13 \% \\ \text { 11.Book value over market value of equity } 53 & 3.12 \% & 6 \% \\ \text { 12.Dividend yield } & 144 & 8.47 \% & 17 \% \\ \text { 13.Tobin's q } & 23 & 1.35 \% & 2.7 \% \\ & 1700 & 100 \% & \end{array}$

G. If you use technical analysis, which particular technique do you use?

Answer

1. Head and shoulders

2. Moving average

3. Momentum

4. Confidence index

5. Margin debt

6. Breadth of the market

7. Block Uptick-Downtick ratio

8. Support and resistance level

9. Relative strength

10. Bar charting

11. Point and figure chart

12. Multiple indicator charts

13. Volume

14. Bullishness on stock index futures

15. Mutual fund cash position

$\begin{array}{llc}\text { Count } & \text { Percent } & \text { (Technical Analysis Count) } \\ 116 & 8.29 \% & 34 \% \\ 222 & 15.86 \% & 65 \% \\ 161 & 11.50 \% & 47 \% \\ 81 & 5.79 \% & 23 \% \\ 29 & 2.07 \% & 8.5 \% \\ 22 & 1.57 \% & 6.4 \% \\ 13 & 0.93 \% & 4 \% \\ 268 & 19.14 \% & 78 \% \\ 148 & 10.57 \% & 43 \% \\ 76 & 5.43 \% & 22 \% \\ 23 & 1.64 \% & 7 \% \\ 42 & 3.00 \% & 12 \% \\ 83 & 5.93 \% & 24 \% \\ 26 & 1.86 \% & 7.6 \% \\ 24 & 1.71 \% & 7 \%\end{array}$




$\begin{array}{clll}\text { 16. Credit balances in brokerage accounts } & 32 & 2.29 \% & 9.4 \% \\ \text { 17. Investment advisory opinion } & 34 & 2.43 \% & 10 \% \\ \text { Total } & 1400 & 100 \% & \end{array}$

H. What method do you use to derive the discount rate (cost of equity) to discount the cash flows to present values?

\begin{tabular}{lll}
\multicolumn{1}{c}{ Answer } & Count & Percent \\
1.Capital Asset Pricing Model (CAPM) & 905 & $53.24 \%$ \\
2.Arbitrage Pricing Theory (APT) & 430 & $25.29 \%$ \\
3.Dividend yield plus growth & 365 & $21.47 \%$ \\
$\quad$ Total & 1700 & $100 \%$
\end{tabular}

I. If your portfolio is only designed to invest in Shariah-compliant shares of Saudi companies, what is the minimum purity percentage level of firms you may wish to invest in? (i.e., I only invest in firms that are... )

\begin{tabular}{lll}
\multicolumn{1}{c}{ Answer } & Count & Percent \\
1. 100\% Pure & 3 & $17.65 \%$ \\
2. 70\% > Pure & 6 & $35.29 \%$ \\
3. 70\% - 50\% Pure & 3 & $17.65 \%$ \\
4. 50\% > Pure & 3 & $17.65 \%$ \\
5. I prefer not to answer & 2 & $11.76 \%$ \\
\multicolumn{1}{c}{ Total } & 17 & $100 \%$
\end{tabular}

J. What kind of educational background and/or professional certificates do you have?

$\begin{array}{lll}\text { Answer } & \text { Count } & \text { Percent } \\ \text { 1. MBA } & 8 & 33.33 \% \\ \text { 2. CFA } ® & 2 & 8.33 \% \\ \text { 3. CPM } & 1 & 4.17 \% \\ \text { 4. CPA } & 1 & 4.17 \% \\ \text { 5. FRM } & 0 & 0.00 \% \\ \text { 6. CWM } & 0 & 0.00 \% \\ \text { 7. CME-1 } & 7 & 29.17 \% \\ \text { 8. CME-2 } & 2 & 8.33 \% \\ \text { 9. CME-3 } & 0 & 0.00 \% \\ \text { Total } & 24 & 100 \%\end{array}$

K. How would you rate your performance, i.e., the rate of return adjusted for risk such as in a Sharpe or Treynor measures?

$\begin{array}{lll}\text { Answer } & \text { Count } & \text { Percent } \\ \text { 1. Excellent } & 5 & 29.41 \% \\ \text { 2. Good } & 8 & 47.06 \% \\ \text { 3. Average } & 2 & 11.76 \% \\ \text { 4. Below average } & 2 & 11.76 \% \\ \text { Total } & 17 & 100 \%\end{array}$

L. If you follow any other additional indicators/theories from the 11 questions aforementioned, please write them below by indicating the question number and the usage of your indicator or theory.

Comment 1 received on 01/28/2015: background and/or professional certificates: ICertIM

Comment 2 received on 02/01/2015: background and/or professional certificates: M.ENG 
Comment 3 received on 02/01/2015: background and/or professional certificates: CMA

Comment 4 received on 02/01/2015: No.

Comment 5 received on 03/02/2015: Elliot waves analysis

Comment 6 received on 02/03/2015: Elliott waves and my own way of scalping

\section{Appendix E}

Companies are organized in descending order according to the Shariah law with the amount of cleansing for each company.

(Attention: they do not mention Al Rajhi and Albilad Banks because they have their own Shariah law auditor.)

\begin{tabular}{|c|c|c|c|}
\hline Order & Company & $\begin{array}{l}\text { The amount of } \\
\text { cleansing for this year }\end{array}$ & Explanation \\
\hline \multicolumn{4}{|l|}{$\begin{array}{l}4 \text { companies do not appear on their } \\
\text { Financial statements any forbidden or } \\
\text { suspicious loans and revenue }\end{array}$} \\
\hline 1 & Makkah & Nothing & $\begin{array}{l}\text { It does not appear on their Financial statements any } \\
\text { forbidden or suspicious loans and revenue. }\end{array}$ \\
\hline 2 & Nadec & Nothing & $\begin{array}{l}\text { It does not appear on their Financial statements any } \\
\text { forbidden or suspicious loans and revenue. }\end{array}$ \\
\hline 3 & Hail & Nothing & $\begin{array}{l}\text { It does not appear on their Financial statements any } \\
\text { forbidden or suspicious loans and revenue. }\end{array}$ \\
\hline 4 & Jawf & Nothing & $\begin{array}{l}\text { It does not appear on their Financial statements any } \\
\text { forbidden or suspicious loans and revenue }\end{array}$ \\
\hline \multicolumn{4}{|l|}{$\begin{array}{l}9 \text { companies do not have immediate } \\
\text { forbidden loans or bonds but they } \\
\text { invest in companies that have some } \\
\text { of forbidden loans or bonds. } \\
\text { So, everyone who owns these shares } \\
\text { on the day of maturity of the } \\
\text { company's profits, must get rid of the } \\
\text { taboo of return on this investment. }\end{array}$} \\
\hline $\begin{array}{l}5 \\
6 \\
6\end{array}$ & $\begin{array}{l}\text { Tabuk } \\
\text { Food }\end{array}$ & $\begin{array}{l}0.02 \mathrm{RS} \\
0.05 \mathrm{RS}\end{array}$ & $\begin{array}{l}4 \% \text { of their assets of investments are in joint ventures. } \\
5 \% \text { of their assets of investments are in joint ventures. }\end{array}$ \\
\hline 7 & Gypsum & $0.02 \mathrm{RS}$ & $6 \%$ of their assets of investments are in joint ventures. \\
\hline 8 & Saptco & $0.15 \mathrm{RS}$ & $7 \%$ of their assets of investments are in joint ventures. \\
\hline 9 & Alarabiya & $0.15 \mathrm{RS}$ & $16 \%$ of their assets of investments are in joint ventures. \\
\hline 10 & Cars & $0.20 \mathrm{RS}$ & $40 \%$ of their assets of investments are in joint ventures. \\
\hline 11 & Gas & $0.30 \mathrm{RS}$ & $52 \%$ of their assets of investments are in joint ventures. \\
\hline 12 & Mubard & $0.07 \mathrm{RS}$ & $54 \%$ of their assets of investments are in joint ventures. \\
\hline 13 & Desert & $0.60 \mathrm{RS}$ & $65 \%$ of their assets of investments are in joint ventures. \\
\hline
\end{tabular}

\section{Copyrights}

Copyright for this article is retained by the author(s), with first publication rights granted to the journal.

This is an open-access article distributed under the terms and conditions of the Creative Commons Attribution license (http://creativecommons.org/licenses/by/4.0/). 